\title{
Wide-Lens Angle: International Students' Constructions of Academic Support in a Selected South African University
}

\author{
Peace Ginika Nwokedi*
}

University of KwaZulu-Natal, South Africa

Fumane Portia M.K. Khanare

University of the Free State, South Africa

\author{
*Corresponding Author: Email: peaceginika@ rocketmail.com \\ Address: University of KwaZulu-Natal, Edgewood campus South Africa.
}

\section{Introduction}

The increase in the number of students who drop out from South African universities are alarming. Heleta (2017) reports that tens of thousands of students leave the university every year without completing their degrees due to lack of academic support, financial constraint as well as workload, health issues, age, family background and lack of balance in study and life (Edwards 2016).

Academic support is very vital and regarded as one of the major responsibilities of universities globally. In context, universities are obligated to ensure that all their students are academically supported (Department of Higher Education and Training (DHET) 2013). DHET (2013, p. 11) policy indicates that its main objective is to "improve and build appropriate diversity within the universities ... and provide learning programmes, modes of learning, methods of teaching and assessment for diverse students' bodies that would support flexibility and innovations." Drawing from the above view, this paper explores international students' constructions of academic support in a selected South African university and showcases their experiences in South African universities. The following question was used to conduct this study: What are the international students' constructions of academic support in a South African university?

\section{Definition of Academic support}

The term 'academic support' is defined as an activity designed and developed to assist or help students succeed in their academics as well as contribute to students learning retention and attendance (Green and Milbourne 1998; US Department of Education 2018). Academic support could also be regarded as the diverse teaching and learning methods, resources and academic services provided by universities to support their students in achieving their learning goals. This implies that providing academic support could lower students university attritions rates (Edwards 2016), transform their lives (Heleta 2017) and create inclusive learning and social environment where international students could interact and engage meaningfully with their host, engage in collaborative learning and acquire intercultural experiences (Farnsworth 2018).

\section{International Students Experiences}


International students are a heterogeneous group of students with diverse identities, knowledge, ideas, attitude, perceptions and voices (Nwokedi 2015). A considerable body of literature reveals that their experiences in their host environment are complex. For instance, literature shows that international students experienced difficulties such as language barriers, exclusion, xenophobia, alienation, low self-esteem, cultural adjustment, isolation, emotional and accommodation issues, financial constraints, lack of academic support and exploitation (Bennett 2014; Maharaj, Perumal, and Perumal 2011; Majyambere 2012; O'Reilly, Hickey, and Lilly 2013, Rajpal 2012) which affected their growth, development and learning in their host environment. Other studies identified their positive experiences such as enhanced learning skills and knowledge, increased self-awareness, improved attitudes (Gu, Schweisfurth and Day, 2010), and academic support (Arkoudis and Tran 2010; Coller and Kuo 2014) which enabled them to function effectively within their host countries was identified too. Borg and Cefai (2014) argue that gaining academic support enables international students to adjust to their academic life easily and help them adapt to their host culture and environment (Wu, Garza, and Guzman 2015).The above literature reviewed shows the significance of this paper which aims to contribute to research on the complex nature of academic support in higher education, particularly, drawing from the voices of the existing international students at a selected university in South Africa.

\section{Methodology}

This study adopted a qualitative case study approach to understand the international students' construction of academic support using flexible methods to generate data (Hogan, Dolan, and Donnelly 2009). Focused group discussion (Cohen, Manion, and Morrison 2011) and photovoice participatory method (Mitchell 2011) was used to generate data from 12 full time international students selected through a convenience and purposive sampling technique (Struwig and Stead 2013). The participants were selected based on their enrolment in the undergraduate and postgraduate programmes for more than 2 years and for living in the campus residence at the selected university in the KwaZulu-Natal province in 2019. The data for this paper was thematically analysed (Tesch 1990) and the issues of trustworthiness were ensured while ethics in research was also considered (Cohen, Manion, and Morrison 2011).

\section{Findings and discussion}

The main findings are illustrated under 3 broad themes.

\section{Theme 1: Academics as source of support}

All the international students attributed their academic growth and development based on the support they get from their lecturers and supervisors. The participants see their supervisors as a source that they draw their learning experiences from. As they indicate them to be helpful and supportive to their studies. This is seen in the case of Zach when explaining his photograph: 


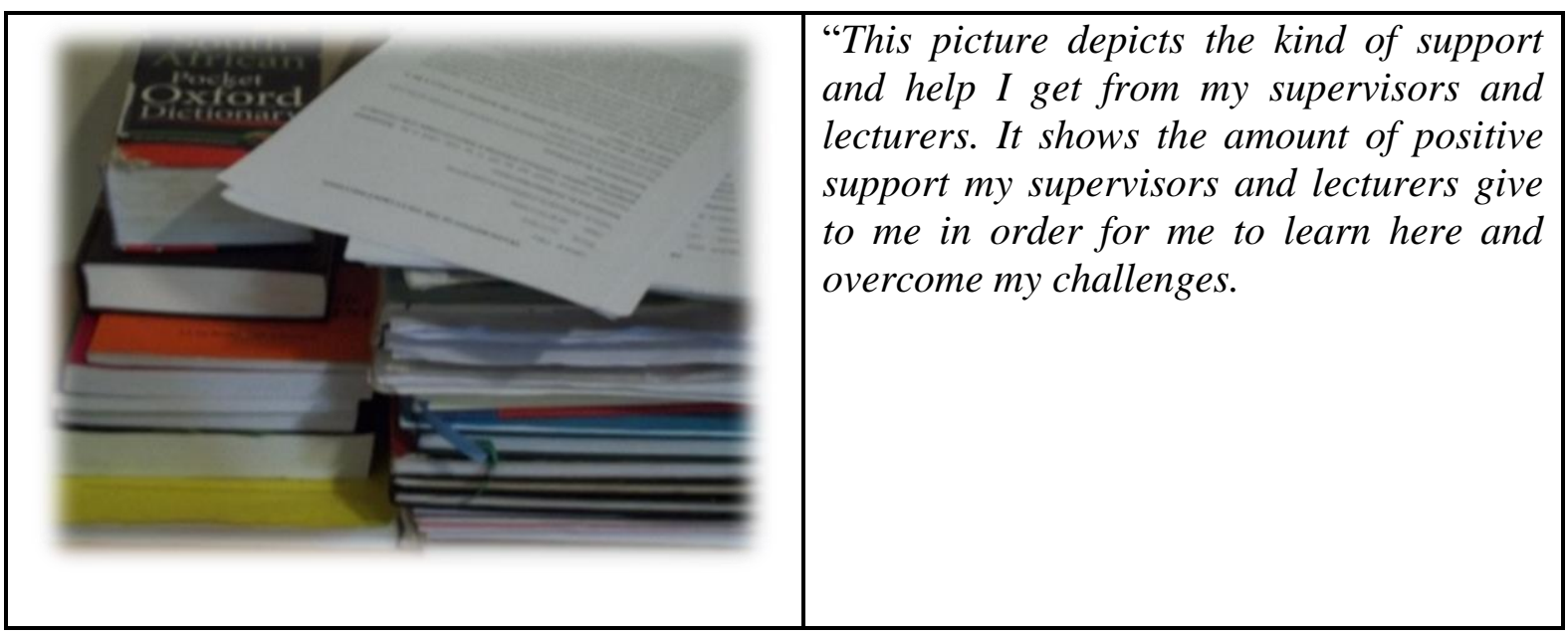

Figure 1 Books and academic materials

Some of the participants also identified that their lecturers' and supervisors' support has helped them in growing academically and achieving their academic goals. John a student from China indicated:

"The support from my supervisor has brought me this far in achieving my academic goals"

The findings above showed academics (lecturers/supervisors) supports the international students in their learning. Arkoudis and Tran (2010) pose that the support international students receive from their lecturers and supervisors is vital in helping them attain their academic goals.

\section{Theme 2: Open learning spaces as a support system}

Another theme that emerged relates to the physical spaces and building such as library, conference and seminar rooms, research commons and LAN created for the students (local and international) in the university to use for their learning. This is illustrated in Figure 2, where one of the participants (Greg) took a picture of the computer room, normally known as 'LAN'.

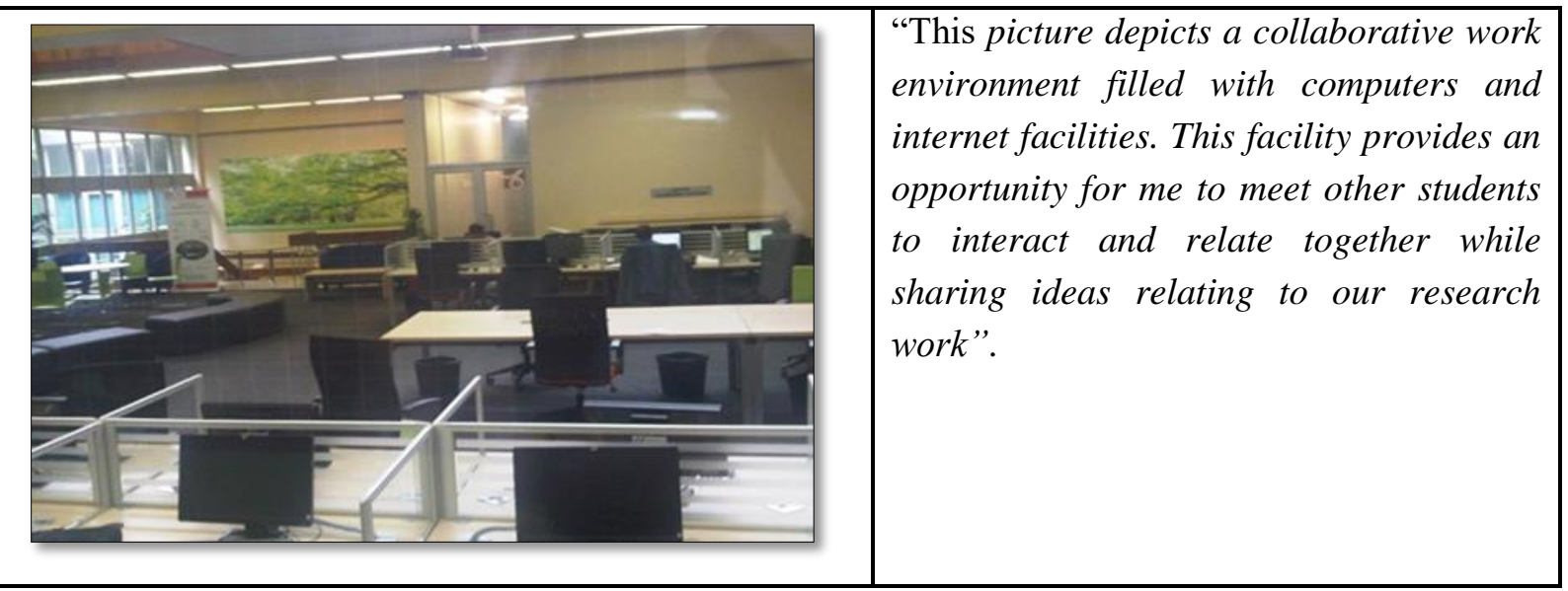

Figure 1 A collaborative work environment

The findings depict that international students identified the open learning spaces as a conducive learning environment within the university that support their learning. Similarly, the findings of Campbell and Li (2008) showed that international students' experience favourable learning environment which positively impact on their learning and allows collaborative learning (Farnsworth 2018).

\section{Theme 3: The teaching and learning programmes}


All the participating international students regarded the teaching and learning activities such as seminars, research cohorts, workshop and conferences organised for them by the university as a support to their learning. The participants view these teaching and learning programmes as a resource that they draw their learning experiences from as they indicate them to be helpful to their learning experiences.

Linda stressed:

"Programmes like research cohort, seminars, workshops, which I enjoyed in my cluster impacts positively towards my learning. As an international student, I learn how to share ideas and information's together, support each other in our research work and do collaborative learning... which helped to develop my creative skills and ability to think critically while doing my studies on this campus".

Jane also alluded:

"The support from this different teaching and learning programmes really helped me and has brought me this far in achieving my academic goals".

The findings suggest that the above academic activities have a fundamental role to play in the international students' learning. The teaching and learning programmes identified by the participant in this study created opportunity for them to share ideas, support each other and work together. Indeed, the findings are consistent with those of Campbell (2010) and Kelly (2010) that international students generated diverse perceptions and personal growth to become independent thinkers and change agents.

\section{Conclusion}

Significantly, the findings of this study revealed that the international students reported a slightly higher level of agency towards their academic activities. A possible explanation may be found in the support gotten from the academics, open learning spaces and the diverse set of university activities that international students' access for support. This paper concludes that integrating photovoice into research with students enables them develop awareness of self and environment as well as enable critical dialogue amongst them using artefacts.

\section{References}

Arthur, Nancy and Natalee Popadiuk. 2013. "International Students' Views of Relationship influence on Career Transitions." Journal of Educational and Social Research 3(7): 273-285.

Borg, Claire and Carmel Cefai. 2014. "Stress, Health and Coping Among International Students at the University of Malta." $2^{\text {nd }}$ Monograph in Resilience and Health. Msida: Centre for Resilience and Socio-Emotional Health, University of Malta, Malta. https://pdfs.semanticscholar.org/1 ce3/3ad619687c01e5cf0ffe9987b69626505486.pdf.

Brown, Lorraine. and Jimmy Holloway. 2008. "The Adjustment Journey of International Postgraduate Students at an English University: An Ethnographic Study." Journal of Research in International Education 7(2): 232-249.

Campbell, Anne. 2010. "Developing Generic Skills and Attributes of International Students: The (Ir) Relevance of the Australian University Experience." Journal of Higher Education Policy and Management 32(5): 487-497.

Cohen, Louis, Lawrence Manion and Keith Morrison. 2011. Research Methods in Education. London: Routledge.

Coller, Ryan and Alice Kuo. 2014. "Youth Development Through Mentorship: A Los Angeles School-Based Mentorship Program Among Latino Children." Journal of Community Health 39(2): 316-321.

Edwards, Stephen. 2016. "School Dropout: A Global Issue. 'ENGAGE' The International Journal on Research and Practice of Students Engagement. http://www.dropoutprevention.org/engage-backup/global-dropout-issue/. 
$\mathrm{Gu}$, Qing, Michele Schweisfurth and Christopher Day. 2010. "Learning and growing in a 'foreign'context: Intercultural experiences of international students." Compare 40(1): 7-23.

Farnsworth, Brand. 2018. "Enhancing the Quality of the International Student Experience." Higher Education Today. https://www.higheredtoday.org/2018/07/02/enhancing-quality-international-student- experience/, 2018.

Heleta, Savo. 2017. “How Strong Academic Support Can Change University Students' Lives.” Sowetan live. https://www.sowetanlive.co.za/news/2017-03-03-how-strong- academic-support- can-change-universitystudents-lives/.

Hogan, John, Paddy Dolan and Paul Donnelly. 2009. "Approaches to Qualitative Research: Theory and its Practical Application." Cork, Ireland: Oak Tree Press.

Lillyman, Sue and Clare Bennett. 2014. "Providing a Positive Learning Experience for International Students Studying at UK Universities: A Literature Review." Journal of Research in International Education 13(1): 63-75.

Kelly, Darren. 2010. "Student Learning in an International Setting." New Directions for Higher Education 2010(150): 97-107.

Maharaj, Preesha, Rubeshan Perumal and Sadhasivan Perumal. 2011. "Perceptions of International Students on the Challenges of Diversity Management at a South African University." Alternation Special Edition 4(1): 203-227.

Majyambere, Moise. 2012. "Information Needs and Information Seeking Behaviour of International Students at the University of KwaZulu-Natal, Pietermaritzburg Campus." PhD diss., University of KwaZulu-Natal, Pietermaritzburg.

Mitchell, Claudia. 2011. Doing Visual Research. Los Angeles: Sage.

Moores, Lisa. and Natalee Popadiuk. 2011. "Positive Aspects of International Student Transitions: A Qualitative Inquiry." Journal of College Student Development 52(3): 291-306.

Nwokedi, P. 2015. "International Students Learning Experiences in a Selected South African University.” MEd diss. University of KwaZulu-Natal, Pinetown.

O'Reilly, Aileen, Tina Hickey and Dermot Ryan. 2013. "Higher Education Professionals' Perspectives on International Student Experiences of Life and Learning in Ireland: A Qualitative Study." Irish Educational Studies 32(3): 355375.

Pilote, A. and Asmaa Benabdeljali. 2007. "Supporting the Success of International Students in Canadian Universities." Higher Education Perspectives 3(2):24-46.

Rajpal, Roseann. 2012. "Educational Journeys of International Postgraduate Students Studying at UKZN (University of KwaZulu-Natal): A Narrative Inquiry." PhD diss., University of KwaZulu-Natal, Durban.

South Africa DHET. 2013. "White Paper for Post-School Education and Training: Building an Expanded, Effective and Integrated Post-School System." Department of Higher Education and Training. Pretoria: Government Printers.

Struwig, Fredrika and Graham Stead. 2013. Research: Planning, Designing and reporting. Cape Town: Pearson.

Tesch Renata. 1990. "Qualitative Research”. New York: Falmer Press.

U.S. Department of Education. 2019. Issue Brief: Academic Support Classes. https://www2.ed.gov/rschstat/eval/highschool/academic-support.pdf.

Wu, Hsiao-ping, Esther Garza and Norma Guzman. 2015. "International Student's Challenge and Adjustment to College." Education Research International (2015):1-9. https://www.hindawi.com/journals/edri/2015/202753/. 